\title{
Living on the Edge: Inughuit Women and Geography of Contact
}

\author{
Genevieve M. LeMoine, ${ }^{1,2}$ Susan A. Kaplan ${ }^{1}$ and Christyann M. Darwent ${ }^{3}$
}

(Received 19 February 2016; accepted in revised form 31 May 2016)

\begin{abstract}
The women of northwestern Greenland experienced contact with Euro-American men in multiple ways and in a variety of geographical contexts. Together the archaeological record and unpublished historical documents reveal the complexities of these situations and women's responses to them. Archaeological and documentary data from two early 20th-century contact situations at Iita in northwestern Greenland and Floeberg Beach on Ellesmere Island, Nunavut, highlight the varied nature of women's responses to contact and the ways in which interaction with newcomers affected them individually and collectively. The women's responses varied over time and across space. They responded to both the stresses and the opportunities of contact with resilience and resistance, acceptance and rejection, depending on circumstances.
\end{abstract}

Key words: Inughuit; Robert E. Peary; George Wardwell; Floeberg Beach; Cape Sheridan; Ellesmere Island; Nunavut; women; pibloktoq; 'Arctic hysteria'

RÉSUMÉ. Les femmes du nord-ouest du Groenland sont entrées en contact avec les hommes euroaméricains de plusieurs manières et dans divers contextes géographiques. Ensemble, des dossiers archéologiques et des documents historiques inédits révèlent les complexités de ces situations et la réaction des femmes vis-à-vis de celles-ci. Les données archéologiques et documentaires de deux situations de contact datant du début du $\mathrm{XX}^{\mathrm{e}}$ siècle à Iita, dans le nord-ouest du Groenland et à Floeberg Beach sur l'île d'Ellesmere, au Nunavut jettent la lumière sur la nature variée des réactions des femmes face au contact et sur la façon dont l'interaction avec les nouveaux venus les ont touchées, individuellement et collectivement. La réaction des femmes variait en fonction du temps et de l'espace. Elles ont réagi au stress et aux opportunités avec résilience et résistance, acceptation et rejet, selon les circonstances.

Mots clés : Inughuit; Robert E. Peary; George Wardwell; Floeberg Beach; cap Sheridan; île d'Ellesmere; Nunavut; femmes; pibloktoq; hystérie arctique

Traduit pour la revue Arctic par Nicole Giguère.

\section{INTRODUCTION}

This paper draws on archival and archaeological evidence to examine some of the ways in which Inughuit women from northwestern Greenland reacted to intense contact with the men of Robert E. Peary's 1905-06 and 1908-09 North Pole expeditions. For each of these expeditions, Peary brought some 20 Inughuit families (including children), representing nearly a quarter of the population of the region, from Greenland to Cape Sheridan on northern Ellesmere Island, where he established a base. Peary hired whole families because he needed the work of both men and women. Although activities such as hunting and sledging by men dominate accounts of these and most other Arctic expeditions, the work of women, in particular the warm fur clothing and footwear they sewed, was a crucial element and essential to the safety of everyone involved. Nevertheless, women and their experiences have been essentially written out of the literature of Arctic exploration (Weisburger, 2010). Here we show how women reacted to a number of specific stresses they faced while living at Cape Sheridan.

These expeditions were difficult on many levels for all who participated in them. Far from their homes and extended families, they were living in close quarters with unfamiliar people with strange habits, and often deprived of the familiar foods and tools of their daily lives at home. Inughuit and Euro-American men also faced physical challenges that tested their endurance and courage as they sledged long distances in very difficult conditions. But the small group of Inughuit women on these two expeditions faced additional challenges of a different sort. Their husbands were away on hunting and sledging trips for weeks and months at a time while they lived at Cape Sheridan surrounded by Euro-American men, mostly the ship's crew, who were not part of the sledging trips. The women were largely dependent on these men for supplies, but were certainly also subject to sexual harassment. To make matters worse, for long periods of time communication would have been rudimentary at best,

\footnotetext{
${ }^{1}$ The Peary-MacMillan Arctic Museum and Arctic Studies Center, Bowdoin College, 9500 College Station, Brunswick, Maine 04011-8495, USA

${ }^{2}$ Corresponding author: glemoine@bowdoin.edu

${ }^{3}$ Department of Anthropology, 330 Young Hall, One Shields Avenue, University of California, Davis, California 95616-8522, USA

(C) The Arctic Institute of North America
} 
as the few people fluent in Inuktun (in particular, Peary and Matthew Henson) were also away for long stretches of time. Here we will examine these challenges in more detail, using historical and archaeological data to show how Inughuit women met them with resistance and with resilience. We begin with historical background to contextualize the specific circumstances of these two expeditions and to present the archival and historical data that form the basis of our arguments. We then examine some of the geographical and technological factors that shaped Inughuit women's experiences at Cape Sheridan.

\section{HISTORICAL BACKGROUND}

The Inughuit (also known as the Polar Inuit and a variety of earlier names) famously first encountered Western culture in 1818, when Captain John Ross, sailing northward in Baffin Bay searching for a Northwest Passage, arrived at Cape York. Ross had with him Hans Zakaeus (John Sacheuse), an Inuk from West Greenland, who acted as interpreter and who learned in conversations with the hunters visiting the ship that Ross and company were the first Westerners to reach this small, isolated group (Ross, 1819; Gilberg, 1996). Through the remainder of the 19th century, the Inughuit met and traded with increasingly frequent visitors, including both whalers and explorers. These encounters were typically brief until the 1850 s, when Elisha Kent Kane began his first overwintering expeditions (Kane, 1856). In subsequent years others followed (Hayes, 1867; United States Navy Dept. et al., 1876), about one per decade, but it was not until the 1890s that visits from the south became almost a routine occurrence.

At the same time as Euro-American visitors were becoming more common, the Inughuit were also visited by Inuit from Baffin Island. In the 1860s, the shaman Qitdlarssuaq led a group of followers on a years-long journey to northwestern Greenland (Ulloriaq, 1985; MaryRousselière, 1991). This small group of families integrated into Inughuit society and was, according to some, key to Inughuit survival (Gilberg, 1974/75). One of their key contributions was to re-introduce technologies, including kayaks and bows and arrows, which the Inughuit had lost some generations back. Their loss was likely related to a sudden population decline due to a massive epidemic (LeMoine and Darwent, 2016). As Gilberg (1976:38) reports, the Baffin Inuit group, although small, ultimately made such a significant contribution to the overall stability of the population that 100 years later some $38 \%$ of the population could trace some of their ancestry back to these migrants.

Robert Peary (1898) first visited the area in 1891 and was in some ways the most influential of the Euro-American newcomers. There were others as well, however, most notably the Danish Literary Expedition of 1903-04, which first brought Knud Rasmussen (1908) to the area. His experiences that year would prompt him to establish the

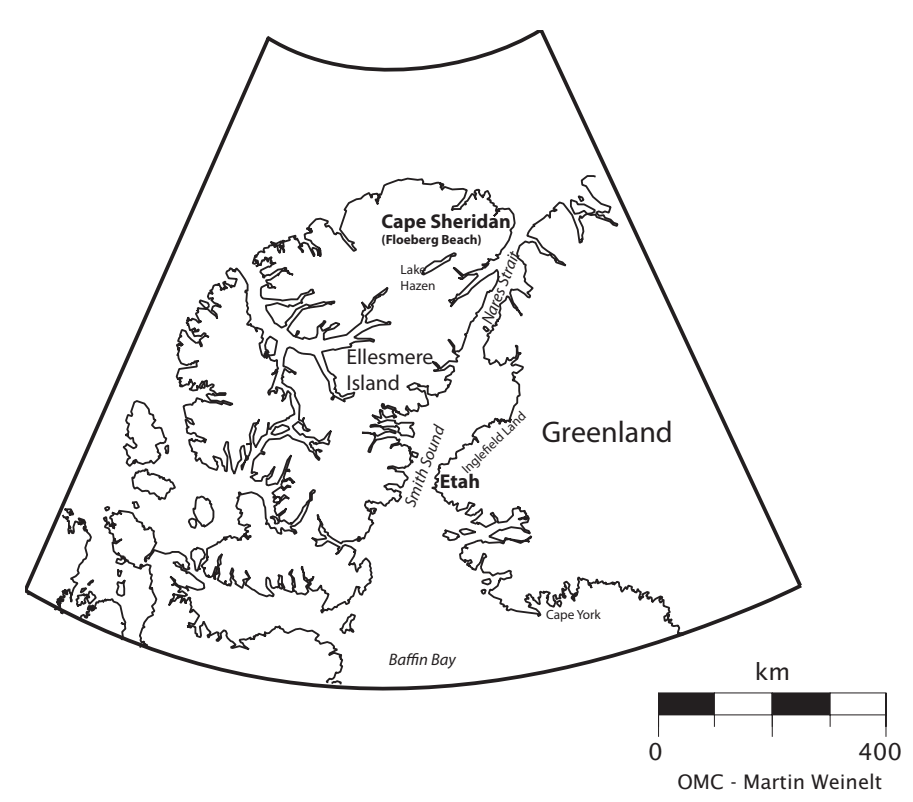

FIG. 1. Map showing the location of sites mentioned in the text.

Thule trading station in 1910, ensuring for the first time that Inughuit had reliable ongoing access to trade goods, and incidentally funding his many Thule expeditions (Gilberg, 1988). Here, however, it is Peary's work that is of interest.

Between 1891 and 1909, Robert Peary lived and worked among the Inughuit off and on for a total of about 7.5 years, including one four-year stretch in 1898-02 (Peary, 1898, 1907, 1910). At some level, he knew just about everyone in this small community of fewer than 300 people, and some he knew very well, having worked with them for extended periods. In all those years his attempts to reach the North Pole had come to naught, but by 1905 he had learned many lessons from his experiences and had a new plan. With a custom-built, ice-strengthened vessel, the SS Roosevelt, and the best ice-captain he could find, Robert A. Bartlett, he would sail as far north as humanly possible to establish an overwintering base on the northeastern coast of Ellesmere Island (Fig. 1). From there teams of American and Inughuit men would spend the fall and winter hunting to provision the expedition and driving heavily loaded dogdrawn sledges to relay supplies to the far north coast, ready for a dash to the Pole as soon as there was enough light by which to see (Peary, 1907). For this work, Peary needed skilled dog-sled drivers, hunters to provide fresh meat for people and dogs, and seamstresses to sew clothing for the team. He had long since learned that separating families for long periods was counterproductive, and so he recruited some 50 people, mostly families (including children) from the scattered summer settlements of northwestern Greenland. Most of the men and many of the women were known to him and had worked for him before, but never so many, and never so far from home. It is impossible to know why families decided to work for Peary in such difficult circumstances. It is clear that he based his hiring exclusively on the skills of the men, selecting "the pick and 


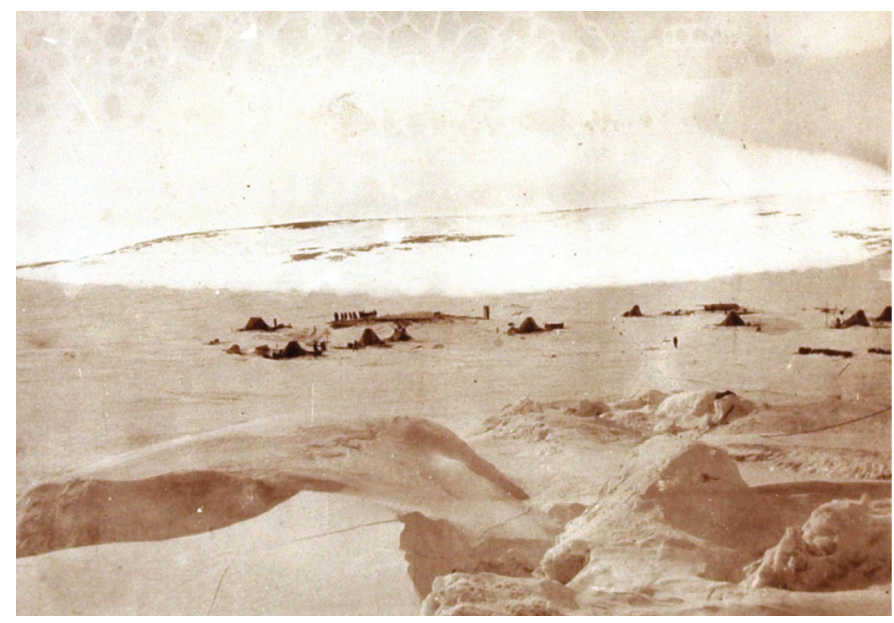

FIG. 2. Inughuit tents at Floeberg Beach. Photo by George Wardwell, ca. 1905-06 or 1908-09. Courtesy of the Castine Historical Society.

flower of the hunters of the whole tribe" (Peary, 1910:43) on the assumption that their wives would accompany them and act as seamstresses. Peary's own perspective is that men chose to work with him because they trusted and respected him, both to keep them and their families safe and to provide them with ample recompense for their work (Peary, 1910:45). There is some truth in this, and he certainly did reward his workers well with sought-after goods, but whether hunters and their wives felt the same way about joining the expedition is unknown.

To begin with, they all relocated to the ship to work for the expedition. In the late summer of 1905, the Roosevelt left Greenland and steamed north. In September, after an extended battle with the ice, they arrived at Cape Sheridan on northeastern Ellesmere Island. There, Bartlett anchored the ship and allowed it to freeze into the slightly sheltered bay for the winter.

Peary had envisioned that the Inughuit families would live aboard the ship as his men did, and at times some of them did so, but for the most part they had other ideas. Many of them relocated from their cramped shipboard quarters to the shores of Floeberg Beach for some or all of the next year (Fig. 2). In late October, 20 individuals (including children), traveled to Lake Hazen in the interior of Ellesmere Island to spend part of the winter hunting (Peary, 1907:67), albeit rather unsuccessfully, as Peary's previous expeditions in the area had depleted the caribou and muskox populations (Dick, 2001). Through the winter, teams of hunters and their families, sometimes accompanied by American members of the expedition team (Peary, 1907:84), spent time at three such settlements, each visiting the ship monthly to share the results of their hunting yield and to restock provisions (Peary, 1907:77). By late February, all had moved back to Cape Sheridan, and most of the men were part of teams sledging north to assist Peary in his attempt to reach the North Pole. Some would be away for weeks, others for months. At the end of the sledging season-during which Peary did not reach the Pole-the families were reunited, and they returned to Greenland in the late summer of 1906.
Although the 1905-06 expedition was not a success, Peary had enough confidence in his methods that he repeated the exercise in 1908-09, returning to Floeberg Beach for another year with many of the same Inughuit families, as well as some newcomers. Again the men hunted throughout the fall, although the hunt was not as productive as in 1905. Women with the expedition set up fox traps and fished in local ponds with some success (Peary, 1910:127). No families overwintered at Lake Hazen, but otherwise things happened much as they had on the previous expedition, with the men away for long periods of time while the women stayed at Cape Sheridan.

In the fall of 1909, Peary departed the area for good, leaving a complex legacy. He was followed in the region by an increasing number of long- and short-term visitors. West Greenlandic missionaries Gustav Olsen and Sechman Rosbach arrived in 1909 to start the first mission station in the region (Gilberg, 1988). Knud Rasmussen established the Thule trading station in 1910, and expeditions such as the American Museum of Natural History's Crocker Land expedition of 1913-17 continued to bring outsiders (MacMillan, 1918).

This relatively recent history of contact and interaction is documented in published and unpublished literature, as well as in photographs. All of the scientific staff with the exception of Ross Marvin (who died in the spring of 1909) published accounts of their experiences, and unpublished journals are available for all except Matthew Henson and Robert A. Bartlett. We have also had the good fortune to study the journals of George Wardwell, chief engineer of the Roosevelt. Of all the crew members whose journals survived, Wardwell was the only one who spent the entire time, in both years, with the vessel at Cape Sheridan. There are no extant Inughuit accounts of the expedition.

\section{ARCHAEOLOGICAL CONTEXTS}

In addition to published and archival sources, we have been investigating various aspects of contact between Inughuit and explorers through fieldwork in Greenland by the Inglefield Land Archaeology Project (ILAP) (Darwent et al., 2007; LeMoine and Darwent 2010, 2016) and on Ellesmere Island (LeMoine and Kaplan, 2011). Here we compare data from Greenland and Ellesmere Island as we explore the ways Inughuit women responded to interaction with Westerners in different contexts.

\section{Iita}

Peary's last stop in Greenland on his way to Ellesmere Island was the settlement of Iita (Etah), located at the head of Foulke Fjord, Qaasuitsup Kommunia, Greenland (Fig. 3). The fjord is a resource-rich location, with access to a variety of important hunting areas, from a massive colony of dovekies (Alle alle) in the inner fjord to walrus (Odobenus rosmarus) in the great North Water polynya just outside the 


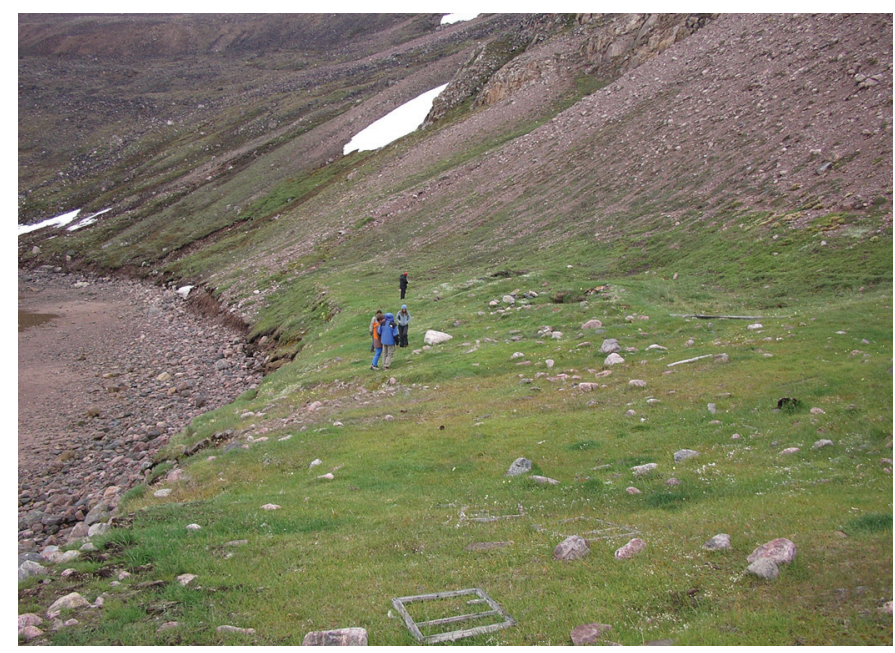

FIG. 3. View of Iita looking west (2006). Photo by John Darwent.

fjord (Darwent and Johansen, 2010). It was an important settlement for Inughuit throughout the historical period, making it a favorite location for overwintering explorers, who could reliably expect assistance from local Inughuit. Kane, Hayes, and the remnants of the Polaris expedition all relied on the inhabitants of Iita for survival (Kane, 1856; Hayes, 1867; United States Navy Dept. et al., 1876).

ILAP excavations in 2006 focused on two semisubterranean Inughuit winter houses, one occupied in the early 20th century and one occupied from the mid-to-late 19 th century to the early 20th century (see LeMoine and Darwent, 2010 for a more detailed discussion). Together these two houses document key aspects of Inughuit responses to contact during these years (LeMoine, 2009; LeMoine and Darwent, 2013). The residents of these houses adopted many Western technologies, such as guns, iron for knives and sled shoes, and cloth for some articles of clothing. But their overall way of life remained much as it had been before. Johansen $(2012,2013)$ analyzed the faunal remains recovered from both houses at Iita in 2006 and detected changes in the proportions of species hunted over time, which she attributed to the adoption of firearms and, after 1909, to the demands of the fur trade (e.g., foxes). But the overall pattern of species exploitation, focused on dovekies and walrus, remained the same: during the period of increasing contact with Western society in the early decades of the 20th century, Inughuit families successfully maintained their traditional way of life (LeMoine and Darwent, 2013).

\section{Floeberg Beach}

Floeberg Beach on Ellesmere Island was occupied three times during the historical period, and not at all in prehistory. Each of the historical occupations is spatially distinct. Captain George Nares of the British Arctic Expedition anchored his ship Alert in the shallow bay between Cape Sheridan and Cape Rawson in 1875 (Fig. 4). As an anchorage it appeared to be exposed, but

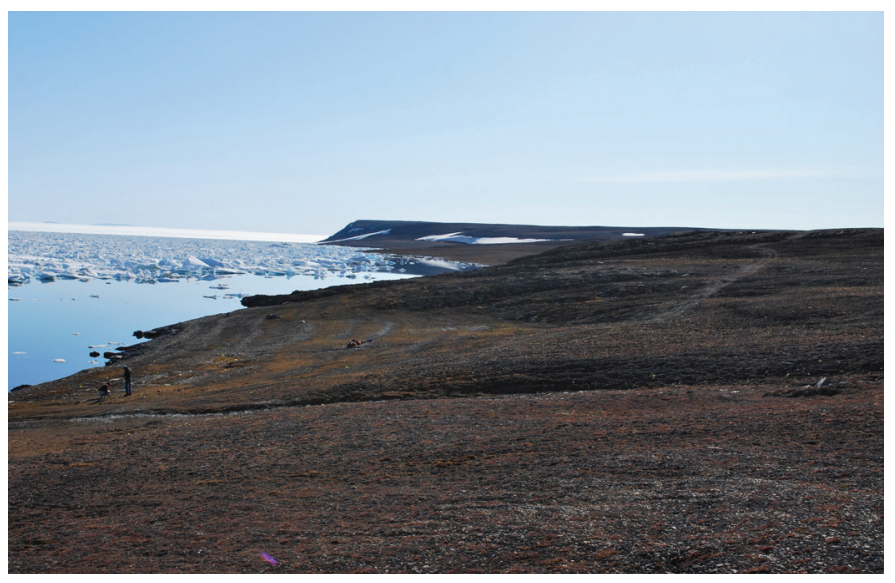

FIG. 4. View of Floeberg Beach looking south (2011). Photo by Frédéric Dussault.

Nares and his men discovered that shoals just offshore meant that larger ice floes grounded there, preventing the active ice pack of Nares Strait from entering the shallow bay and providing a measure of protection (Nares and Feilden, 1878). This feature led them to name the beach "floeberg," a word they coined to describe the massive pieces of old (paleocrystic) ice (Nares and Feilden, 1878(I):131). Nares and his crew lived aboard their vessel, but they off-loaded supplies and constructed a shelter on shore in case the ship was damaged by the ice. The remains of these activities are visible at the south end of the beach. Nares had no contact with Inughuit during his time at Floeberg Beach.

Peary's 1905-06 and 1908-09 expeditions account for the other occupations at this site. Like Nares, Bartlett took advantage of the protection offered by the shoals offshore to keep the Roosevelt safe over two winters. Also like Nares, each year Peary had many supplies transferred from the ship to the shore as a precautionary measure should the ship be crushed by ice. Additionally, Inughuit families constructed homes or erected tents there in preference to living aboard the ship. In 1905, Peary and his team established themselves on the central portion of the beach, while in 1908 they chose a more sheltered location at the north end of the beach. Thus, apart from some inevitable mixing during the occupations, the three occupations are readily identifiable and spatially distinct.

The 1905-06 occupation includes the remains of a poorly defined rectangular structure, probably the large crate house described by Peary (1907:61); a series of tent rings; and two middens composed largely of discarded cans (Fig. 5). Some of these features relate to the Nares expedition (Wardwell, 1905-06), but many are from the later occupation.

The 1908-09 occupation consists primarily of the remains of three small buildings constructed from uniformly sized packing crates custom-made for the purpose (Peary, 1910:125). One of the buildings included a heating stove and was used by Peary's assistant Matthew Henson and others as a workshop for constructing sledges and portable stoves, among other things. 


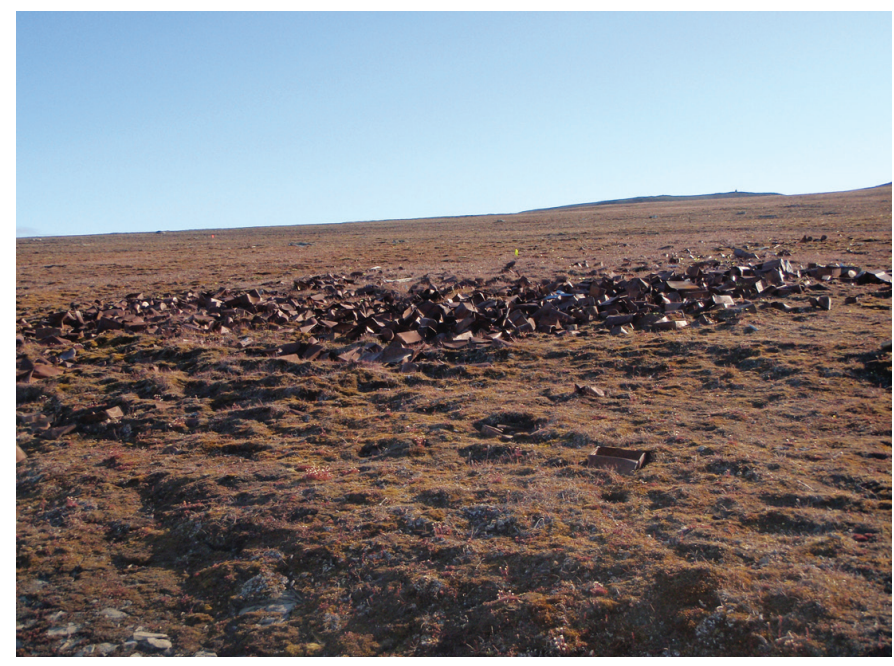

FIG. 5. Midden composed primarily of cans at Floeberg Beach (2011). Photo by Genevieve LeMoine.

The site was first examined archaeologically by Parks Canada as part of a broad survey of historic sites in the High Arctic (Phillips Parmenter et al., 1978; Phillips Parmenter, 1981, 1987; Phillips Parmenter and Burnip, 1980). Over three field seasons, Phillips Parmenter and her teams recorded features at the site, conducted excavations in some of the Peary-related features, including the 1905-06 structure, and collected most surface artifacts to stave off further looting of the site by souvenir collectors. They also noted considerable damage to the surface of the site by tracked vehicles from Canadian Forces Base (CFB) Alert, $16 \mathrm{~km}$ away.

LeMoine and Kaplan (2011) visited the site briefly in 2011 to evaluate its condition some 30 years after the last visit by archaeologists and to determine whether a longerterm project focused on the Inughuit occupations would be productive. They re-mapped and photo-documented the features, collected additional surface samples, and excavated three $1 \times 1 \mathrm{~m}$ test units in the 1908-09 section of the site. They collected a variety of materials - most notably for this discussion, a series of modified cans from the larger midden. They also examined the materials collected by Phillips Parmenter, which are now housed at the Prince of Wales Northern Heritage Centre in Yellowknife. Here we focus on material recovered from two features at Floeberg Beach: the ephemeral remains of the structure built in 1905 and excavated in 1980 and the nearby midden, largely composed of tin cans, re-examined in 2011. Artifacts from these features exist at the intersection of the science and technology of exploration, interpersonal relationships and gendered roles among the Inughuit and Peary's expedition crews, and the inevitably complex agency of the individuals involved.

\section{STRESS AT CAPE SHERIDAN}

Archival and historical sources provide ample evidence for the high level of stress among virtually all the inhabitants of Cape Sheridan. For Inughuit women this stress is most obvious in the numerous cases of pibloktoq or Arctic hysteria reported there. Dick (1995) has convincingly argued that stresses ranging from food insecurity to sexual harassment led to the many episodes of pibloktoq recorded by American and Danish visitors to the Smith Sound region in the late 19 th and early 20 th centuries.

Pibloktoq is an enigmatic condition, first reported by Josephine Peary (1894) and subsequently widely reported among Inughuit women (and some men) in the late 19th and early 20th centuries. Peary (1910) described it as a form of hysteria characterized by screaming or singing, removing some or all clothing, and often running away despite frigid temperatures, but he and others often used the term to describe other behaviors as well, including what are clearly shamanic performances, e.g., a healing ceremony at Fort Conger in 1901 (USNA, 1901; see also Dick, 1995:23). Numerous researchers have attempted to classify pibloktoq as having psychiatric, environmental, or nutritional origins, or some combination of these (Dick, 1995:2, and references therein), and given the broad range of cases identified as pibloktoq by first-hand observers, it is possible that some or all of these origins are important in different cases. After a thorough examination of published and archival records, Dick argues that there is a link between shamanic activities (trances especially) and pibloktoq, and that both are a reaction to stressful situations. He links pibloktoq to behaviors described in Inughuit legends collected by Erik Holtved as pivdlerotoq or "drum dance fit" and associated with times of stress, including starvation, hunting accidents, and other calamities (Dick, 1995:11). Dick cogently argues that Inughuit working for Peary suffered significant stress, which for some individuals found expression in these dramatic episodes.

Dick (1995) has described and documented the many stresses both men and women experienced while working for Peary, including the challenges of being far away from their homes and families, living and working under difficult and unfamiliar circumstances, episodes of food insecurity, and for women especially, sexual harassment. Below we describe archival and archaeological evidence that supports two of these factors, geographic displacement and unfamiliar living and working conditions. While sexual harassment was undoubtedly also significant, we have not uncovered additional evidence to add to Dick's compelling discussion.

\section{From Smith Sound to Nares Strait}

Dick identified 40 confirmed cases of pibloktoq documented in published and unpublished sources between 1892 and 1928, almost all of them in women. He suggests that being away from home was a factor in 27 of the 40 episodes (Dick, 1995:29). Of these, only six in his sample took place at Cape Sheridan, five in 1905-06 and one in 1909. We have uncovered an additional source that was not available to Dick, which dramatically increases the number 
of cases at Cape Sheridan, adding weight to the idea that distance from home is an important contributing factor. The journals of George Wardwell, chief engineer of the Roosevelt on both the 1905-06 and 1908-09 expeditions, have been in family hands and have only recently been made available for study. Wardwell, unlike the authors of all the published expedition reports, did not participate in any sledging trips: he stayed with the vessel the entire time, faithfully writing in his diary every day. Wardwell's reports add considerably to the total number of reported cases of pibloktoq and make it possible to examine the geographic distribution of cases more fully.

Since documentation of cases is determined by the location of the observers, we cannot account for how many (if any) incidents of pibloktoq occurred when no Westerner was present (that is, for example, in Greenland vs. while away working with Peary). However, for 1908 it is possible to compare episodes of pibloktoq observed at Cape Sheridan, among the men and women working for Peary, and those observed by Harry Whitney, a big game hunter overwintering at Iita and Anoritok that same year (Whitney, 1910). In Greenland, where Inughuit families not working for Peary were going about life as usual, Whitney recorded four episodes in the summer and fall of 1908, two each for two individuals. Over the same period at Cape Sheridan, Wardwell reported 21 instances involving 26 individuals, all but two of whom were women. Only one of these instances is included in Dick's list of episodes, as Donald MacMillan also reported it. Dick reports an additional three episodes recorded by others in August of 1908, when the expedition was still at Iita, as well as the four episodes described by Whitney. In total then, 29 individuals experienced episodes of pibloktoq while working for Peary in 1908 compared to four individuals who were at home in Greenland during that time. This large number of episodes is, if anything, an underrepresentation of the reality at Cape Sheridan. On 30 June 1909, Wardwell (1908-09), after reporting no episodes all winter, recorded an instance, writing "they have those spells so often I don't notice it now." Clearly, life for women at Cape Sheridan was significantly more stressful than life at home.

\section{GEOGRAPHY AND STRESS}

Archaeological evidence and ethnographic data support the argument that being away from home was a significant contributing factor to stress at Cape Sheridan. Inuit communities, and by extension their archaeological sites, are deeply rooted in their place. Local and regional geographies simultaneously define and are defined by the ways communities inhabit them. Physical geography, encompassing the material characteristics of the land and water, is of course of vital importance: proximity to key animal habitats and other resources is a major factor in settlement location, and it is the component of geography that archaeologists typically consider when seeking to understand site-location strategies. But for Inuit, as for all human groups, landscape is more than that: it is layered with meaning (Ingold, 1993). For Inuit in particular, Nuttall (1992) has identified landscape as a "memoryscape" expressed in part through place names, which encode a vast array of information that links individuals and communities to the land they inhabit and aids in activities as diverse as hunting and storytelling. Landscape becomes "the physical expression of community" (Nuttall, 1992:59) in which nuna, the land, is a repository of information about not only where to conduct particular activities, but also who has been there, what happened there recently or in the legendary past, or how to conduct oneself there. Whitridge (2004:221) has noted that "place and landscape are closely bound up with personal and collective identity."

Communities stay in the same region for many generations, continually layering the landscape with individual and collective memories, but there are times when individuals or families find themselves in a new, unexplored region, where the landscape and its resources are unfamiliar, even strange. Construction of a memoryscape begins immediately, presumably, but the rich depth of connection that people had with their former home takes time to develop. For newcomers to any area there is much to learn about when and where desirable resources are to be found, for example, before a new land becomes a part of a community. Archaeological data highlight the strong contrast between the memoryscapes of Cape Sheridan and those of Inughuit communities along the northwestern coast of Greenland.

Surveys over the last 10 years by the Inglefield Land Archaeology Project have allowed us to develop a picture of changing land use in this region over the last 4500 or so years (Darwent et al., 2007). The Harstene Bay area, of which Iita on Foulke Fjord is a major feature, was the most densely occupied part of Inglefield Land for thousands of years. In addition to winter houses at concentrated settlements, Thule and historical sites include a wide range of other features from tent rings to caches, fox traps, snare lines, and most poignantly, a large number of children's play features at Jensen Point, where beach cobbles were just the right size for constructing miniature versions of houses, caches, and even fox traps.

It was not only Thule people who made extensive use of the area. Dorset occupations are also abundant; these include the massive Reindeer Point longhouse (Darwent et al., 2008) and multiple occupations at Iita itself (LeMoine and Darwent, 2010; Darwent, 2013). Pre-Dorset people used the region as well, although their occupations are restricted to the outer coast, as they do not seem to have ventured up the fjord. Indeed, there is hardly a spot of level or near-level ground on which there is not some evidence of human occupation. Families that lived here were embedded in a rich, cultural landscape, a many-layered memoryscape, stretching hundreds of kilometers up and down the coast and back in time through many generations. It was, in part, this rich history of occupation that attracted Peary and 
other explorers to the area, for he knew he would find the skilled men and women, hunters and seamstresses, who were crucial to his expeditions.

The landscape of Cape Sheridan is considerably different from that of Foulke Fjord. While the Foulke Fjord region supports a relatively abundant and diverse assemblage of species to sustain human life, the outlook for hunters at Cape Sheridan would have been bleak, to say the least. To begin with, the waters and ice of Nares Strait are inhospitable to marine mammals. The strait is narrow and is a significant outlet from the Arctic Ocean to the North Atlantic. In winter, ice bridges can form across the strait, but even then strong currents push the first-year ice, which is constantly reforming in the newly open water, toward the south (Münchow and Melling, 2008). When ice bridges are not present, the strait is clogged with thick-moving pack ice exported from the Arctic Ocean. Neither of these situations makes for good ringed seal (Pusa hispida), bearded seal (Erignathus barbatus), or walrus habitats, particularly along the exposed coastline of far northern Ellesmere Island.

Hunting on land is not much better; Peary caribou (Rangifer tarandus pearyi) and muskox (Ovibos moschatus) both live in the region, muskox being more plentiful than caribou, but neither species seems to have been abundant. Evaluating the size of these populations in prehistory is difficult. Current populations seem hardly to have recovered from the widespread slaughter conducted by Peary and then by MacMillan between 1898 and 1917 (Dick, 2001:409-412). But even these well-documented hunts took few animals in the immediate vicinity of Cape Sheridan; Peary routinely sent out hunting parties that would travel for days to areas where they might expect to find good hunting. Nor was small game particularly plentiful.

This impoverished environment is directly reflected in the archaeological record. There is scant evidence for any sustained occupation of this part of the coast. The Government of Nunavut Archaeological Sites Database indicates that apart from historic occupations, there are few prehistoric sites, mostly isolated tent rings, with the exception of a single, larger pre-Dorset site west of CFB Alert. Even these sites are some distance away, to the north and west in the Porter Bay area and to the south at Lincoln Bay. The area around Cape Sheridan lacks both a physical environment capable of providing the resources an Inuit family requires and (in part as a corollary to that fact) any established memoryscape. On the contrary, it was for the Inughuit an inhospitable, culturally blank space that would have reinforced women's feelings of alienation and displacement.

The women's experience was quite different from that of their spouses. The men may have felt "at home" more rapidly because they had gained familiarity with the regional landscape while on frequent sledging trips through the fall, winter, and spring (although women participated in some of these trips too). Alternatively, the men may have expressed their alienation in different ways. In particular when out on the sea ice far from land, Peary, MacMillan, and others often reported feelings of unease among the Inughuit men and accused them of feigning illness or being "wrought up by the fear of the Evil Spirits of the Polar Sea" (MacMillan, [1934] 2008:171). Given the very real dangers they were facing, the men's reactions were, if anything, restrained, and we can expect that the women likewise felt themselves to be under considerable stress.

\section{MATERIAL MANIFESTATIONS OF STRESS}

The geographic, historical, and cultural differences between Cape Sheridan and Iita are mirrored in the artifact assemblages recovered from the two sites, where we find evidence on a smaller scale of the difficulties faced daily by Inughuit women as they struggled to keep their families warm, fed, and clothed. In particular, lamps and stoves, key elements for survival in the Arctic, stand out as archaeological evidence of such stress.

\section{Lamps in Inuit Culture}

Lamps have an important role in Inuit culture across the Arctic on many levels, from the functional to the symbolic. In this extreme environment, where wood is rare to nonexistent, sea mammal blubber is a vital source of fuel as well as food. Among the Inughuit, Holtved (1967:26) reports that "white whale is considered best, in that it produces a tall flame without soot. The next best is seal blubber. Walrus blubber is only used when nothing else can be had." For the Inughuit, sea mammal oil burned in shallow, stone lamps is typically the only source of both heat and light, particularly and most importantly during winter. Inughuit women in the early 20 th century, like their ancestors before them, used traditional stone lamps. They continued to use them on a daily basis at least into the 1930s (Holtved, 1967:20), and similar lamps are still used for special occasions today. These lamps are large, shallow, half-moon shaped, dish-like vessels carved from steatite or a similar stone that is relatively easy to work. The wick, usually of moss, is carefully laid along the longest side, and oil is placed in the broad reservoir. The wick requires frequent attention to prevent smoking. Holtved (1967) reported that in the 1930s, shallow copper lamps modeled on stone lamps were common, the copper being obtained from the Thule Trading Station. ILAP also recorded a steel example, cut from a jerry can, at Innuarfissuaq in Inglefield Land, Greenland.

Lamps provide both heat and light. A woman's lamp simultaneously keeps the dwelling warm, sheds light on the work area, heats food and water, and dries clothing. The highly important functional role of the lamp is complemented by an equally important social and symbolic role. Tending the lamp is a strongly gendered activity. As women tend lamps, they maintain the important functions of the house both literally and figuratively (Guemple, 1986; 
Bodenhorn, 1990). A woman's skill at keeping a smokefree flame burning at all times is an important measure of her abilities generally and requires a good deal of practice (Holtved, 1967:126). Symbolically, a woman is understood to be tending the soul of the house, which can also be seen as the soul of the whale, traditionally the most important prey (Oosten, 1986; Saladin d'Anglure, 1986; Lowenstein, 1993). Thus by keeping the lamp burning cleanly, a woman cares for the souls of the whales her husband hunts, an act essential to his success. The act of maintaining the lamp is integral to a woman's identity, as well as to the physical and emotional well-being of her family.

\section{Peary and Stoves}

Lamps and stoves were important to Peary as well. Archival research, supported by his own writing, reveals that Peary (1917) was both meticulous about planning and somewhat obsessed with stoves for northern fieldwork. He understood that to work effectively on arduous sledging expeditions, men needed a reliable source of heat to produce hot water from ice. He continually experimented with new designs for stoves as he attempted to maximize functionality while minimizing the need for fuel so as to reduce the weight carried on sledges. In Peary's papers (USNA, 1798-1976), we identified a number of different designs made between 1886 and 1906, some of which were drawn while actually on board the Roosevelt at Cape Sheridan. It is clear that Peary was thinking about stoves throughout that fall and winter before heading off on the sea ice in February of 1906. In the fall of 1905, he writes that his minimal leisure time while preparing for the expedition left him in a "suitable frame of mind to devise new methods and items of equipment which assisted materially later on. Among the latter was a quick-acting alcohol camp stove, built upon a new principle" (Peary, 1907:79). Ultimately the "Peary Stove" used on the 1908-09 expedition was a model of efficiency - burning alcohol, it turned snow into boiling water in nine minutes, then promptly ran out of fuel (MacMillan, 1934 [2008]:153). The expedition also had a supply of Primus stoves (which ran on kerosene) for use closer to home, as well as larger coal-burning stoves.

\section{Lamps, Stoves, and Cans at Cape Sheridan}

Given the importance of traditional blubber lamps to Inughuit women and Peary's meticulous planning, particularly with regard to stoves, it is surprising to find parts of stoves or lamps made from repurposed tin cans among the artifacts from Floeberg Beach. They seem unlikely to suit the needs of either Inughuit or explorers. Certainly the men of the expedition, Inughuit and European, did not use them on any of their sledging trips.

Some reuse of cans is hardly surprising; there are many historical examples of repurposed cans (e.g., Busch, 1981), and the sheer abundance of cans in the midden at Floeberg Beach must have made them a ready target for experimental reuse. It is clear that the abundant tin cans were a novel raw material for the Inughuit, and they experimented with them. The large midden is littered with cans that have been carefully cut open to flatten them. Numerous cans that have been shaped into boxes, pots, pails, cups, and bowls were collected from the surface in both 1980 and 2011, and many more remain in the midden. Some are skillfully finished and even soldered, suggesting that the Americans had a hand in creating them. But other, sometimes more experimental, forms may be the work of Inughuit men and women.

Of particular interest here, however, are a number of cans that have been reworked into components of ad hoc lamps or stoves, including fuel reservoirs, wick holders, and funnels (Fig. 6). These are likely the work of George Wardwell, the Roosevelt's chief engineer, who reports in his diary on 6 November 1905 that "the boys [meaning members of the ship's crew, probably the firemen under his direct command] have been making tin stovepipes, stoves out of oil cans that was [sic] left here by the Alert, making pails out of the kerosene cans for the Esquimaux [sic]..." (Wardwell, 1905-06). A number of components of such lamps have been recovered from Floeberg Beach. Similar stoves found at two Lake Hazen houses occupied by Peary's Inughuit families during the winter of 1905-06 were reported (though apparently not collected) by Moreau Maxwell (1960).

These lamps or stoves are complex compared to traditional Inughuit design, and they were designed to burn kerosene or alcohol. Since no complete lamps were found, their appearance is somewhat conjectural. The components include a medium-sized rectangular can to serve as a reservoir for fuel. On top of that sits a lid formed by a piece cut from another can, with a lengthwise slit through the middle and a hole for adding fuel (Fig. 6b). The slit is reinforced with a sleeve made from a small round can, with top and bottom removed and then flattened, the sides partially cut and spread to form a flange. This sleeve is inserted through the slit, and the flanges presumably help to hold it in place. Finally, a wick holder made from another flattened round can fit inside; one was even found with the wick still in place (Fig. 6a). Small funnels formed from the lids of round cans would have helped in adding fuel (Fig. 6c). Operating a lamp such as this is different from using a traditional stone lamp, and it seems likely that these lamps were smokier, sootier, and smellier (or at least, smelled very different) than either their more formally constructed counterparts or traditional blubber lamps. Women also would have required access to scissors to trim the wick, which is as important for a kerosene lamp as it is for a traditional seal oil lamp to reduce smoking.

One key reason women may have turned to such lamps is the availability of fuel. A traditional lamp burns oil rendered from sea mammal blubber. As we have seen, however, Cape Sheridan is a remarkably poor place to hunt sea mammals. Peary had both his American and Inughuit employees hunting as much meat as possible, but it was caribou and muskox they were after, and the meat and fat 


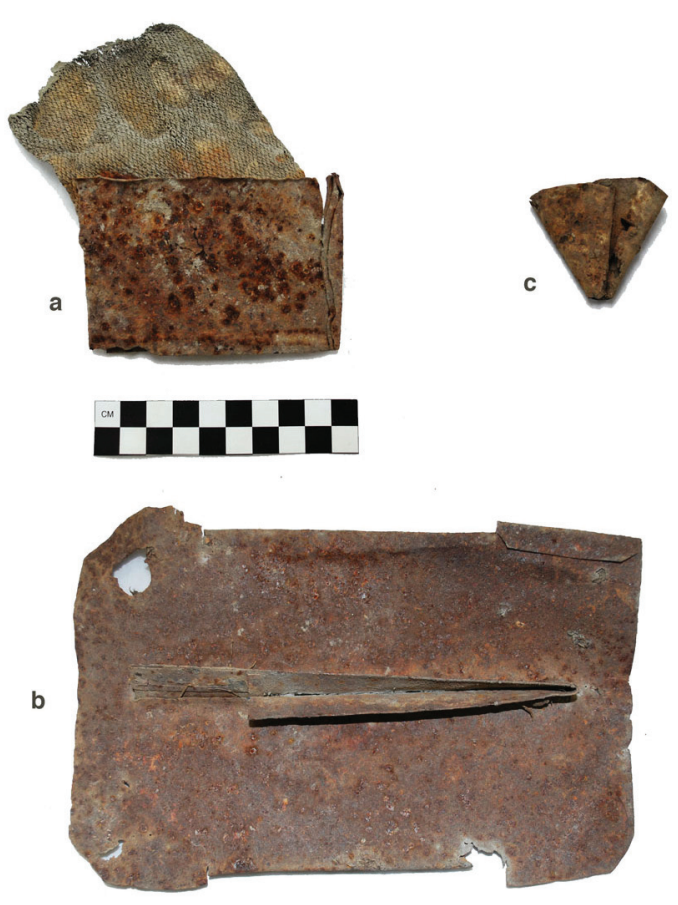

FIG. 6. Lamp or stove components made from tin cans: a) wick holder with wick (PWNHC 985.006.334), b) reservoir top with flange (PWNHC 985.006.2160), c) funnel made from can lid (PWNCHC 985.006.2325). Photos by Susan Kaplan, courtesy of the Prince of Wales Northern Heritage Centre.

were intended to feed humans and dogs. Women seem to have brought their lamps with them, as a single fragment of a stone lamp attests, but they could not possibly have carried enough oil with them from their homes in Greenland to fuel their lamps for the winter, even if they had had sufficient stocks on hand, which is highly unlikely. They appear to have had no choice but to abandon this familiar technology, a potent symbol of their role and skills as women, and make do with ad hoc stoves made from discarded cans, burning a noxious, unfamiliar fuel.

\section{Lamps at Iita}

It is instructive to examine the contemporaneous situation at Iita, where some of the families working with Peary had been living before their trip to Ellesmere. The two Inughuit houses excavated by ILAP in 2006 and described above provide a comparative sample. The assemblages from both houses have evidence of contact in the form of trade goods, imported raw materials, and changes in some types of material culture. For example, we recovered thimbles, needles, and sewn fabric garments. These items are evidence of both the popularity of steel needles for sewing hides and the eventual (post-1910) adoption of fabric for some parts of traditional dress. Cloth anoraks in particular were worn with increasing frequency after 1910, reflecting the influence not of Peary, but of the family of the first Lutheran Pastor in the area, who was from West Greenland, and the availability of cloth from the Thule trading station (LeMoine and Darwent, 2013).
We also found increasing evidence for the use of industrial metals, most commonly in the form of knives, scrapers, and endblades, but also for sled shoes, which were in common use by 1909 (Whitney, 1910). Overall, materials recovered from these two houses indicate a relatively rapid, but fundamentally conservative adoption of Western technology into traditional technological systems. Inughuit were highly selective about what they chose to use and how they chose to use it.

Modified tin cans, so common at Floeberg Beach, were almost nonexistent at Iita, although discarded cans themselves were relatively abundant. Some of the cans recovered were clearly debris from expeditions, most notably Donald MacMillan's Crocker Land Expedition, which had its base at Iita between 1913 and 1917 and used the depression left by House 2 as a disposal area. Items from levels associated with that expedition and later are excluded from the following discussion. Although most cans were highly fragmented, enough were whole or partially complete that if Inughuit at Iita were routinely using cans as a raw material, or even minimally shaping them into useful objects, we would have recovered evidence of them. However, we found only two pieces of modified can: these were strips, identifiable as from cans by the presence of a characteristic seam. There were no metal boxes, containers, bowls, cups, funnels, and certainly no lamps, even in the traditional style. There were, however, soapstone lamp fragments, and these fragments, along with photographic evidence, make it clear that women continued to use traditional lamps well into the 20th century (Fig. 7).

In a mixed early 20th century context in House 1, we also recovered a small number of glass fragments that may be from lamp globes, which should not come as a surprise. Peary (1917:192) gave a number of lamps to his Inughuit employees, along with matches and presumably some fuel. But most Inughuit families would not have had reliable access to fuel even after the establishment of the Thule Trading Station, and they demonstrably continued to use more familiar and reliable blubber lamps at least some of the time into the 1930s. This scenario fits well with the pattern seen in adoption of other elements of technology, which is characterized by conservatism unless there is a clear advantage that enhances rather than disrupts longstanding practice (LeMoine and Darwent, 2013).

The kerosene-burning tin-can stoves recovered from Inughuit habitations at both Floeberg Beach and Lake Hazen, but not at Iita, are material evidence of the extremely difficult situation-physically, socially, and emotionally - that these women experienced while working for Peary at the very edge of the world. That the women at Cape Sheridan had to abandon their familiar and reliable blubber lamps emphasizes the difficult circumstances they faced. Far from home, in an unfamiliar, inhospitable landscape, they lost control of a key part of their identity: their ability to provide warmth, light, and food for their families. The difficulties they faced with these stoves are underscored by the absolute lack of evidence for similar 


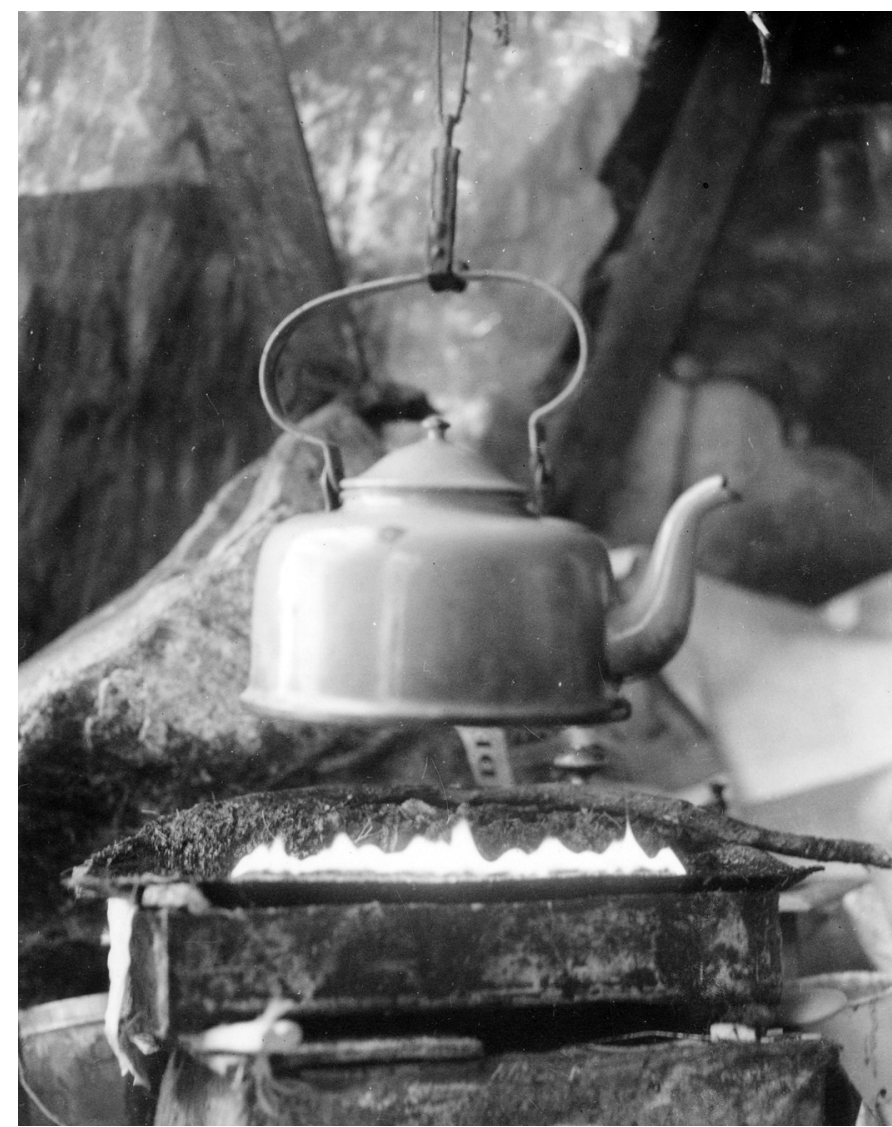

FIG. 7. Soapstone lamp and tea kettle, northern Greenland, 1938. Photo by Donald B. MacMillan. Courtesy of the Peary-MacMillan Arctic Museum and Arctic Studies Center.

stoves in contemporaneous deposits in Smith Sound. They had no use for them at home.

\section{CONCLUSIONS: RESISTANCE AND RESILIENCE}

The circumstances of contact and the entanglement of Inughuit and explorers are complex and multi-faceted. Examination of archival and published sources has led us to characterize the relationships between explorers and Inughuit women at Floeberg Beach as exploitative and fraught with anxiety. Archaeological evidence supports this view of women under considerable stress, living and working among strangers, far from home, and struggling with unfamiliar tools, including those that are at the core of their gendered identity.

Broadening our gaze to include Iita, however, we see a different picture. There, in a familiar environment surrounded by extended family and friends, even when expedition crews were living amongst them, things were different. Episodes of pibloktoq, while not unknown, were much less common. And while Inughuit at Iita had access to new, foreign technologies, they also had the option of picking and choosing what they adopted. As it turns out, they were highly selective, choosing to adopt tools and technologies that enhanced their traditional way of life,

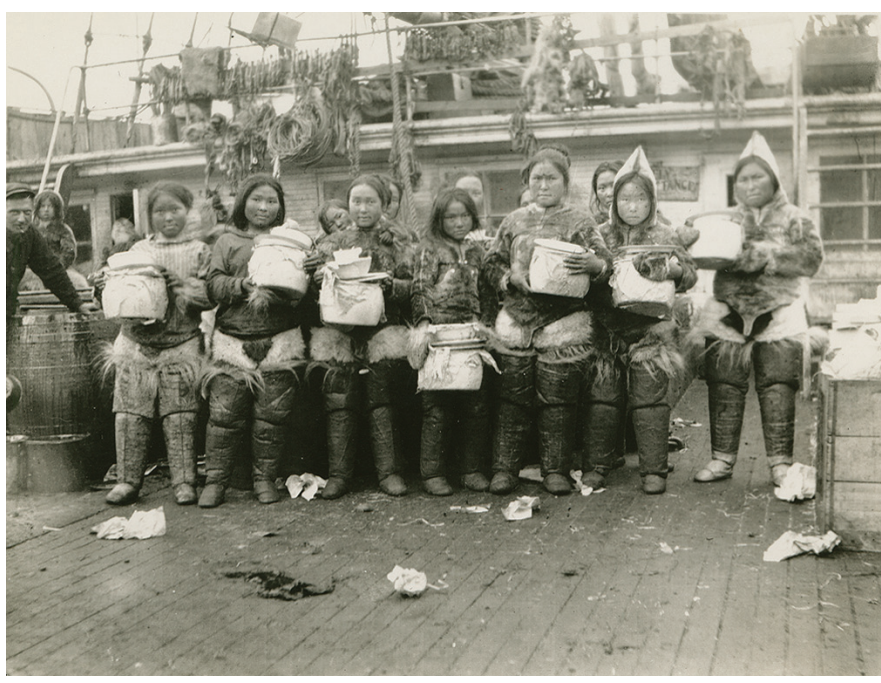

FIG. 8. Women with enamelware pots acquired in partial exchange for their work as seamstresses on the 1908-09 North Pole expedition, aboard the SS Roosevelt, 1909. Photo by Donald B. MacMillan. Courtesy of the PearyMacMillan Arctic Museum and Arctic Studies Center.

such as steel needles and even cloth, while rejecting others, such as kerosene lamps. The women who worked with Peary on Ellesmere Island returned laden with Western material goods (Fig. 8) and found uses for many of them, but by no means for all. There is no doubt that the women were, at some level, traumatized by their experiences. However, they went home with knowledge, too, of what worked and what did not, what was of use to them and what was not. We can speculate that they also returned with a sense of their own resilience, their ability to feed and clothe their families (and others) under extreme circumstances, their ability to adapt to circumstances and to hold on to what was important to them. Canadian Inuit leader Sheila Watt-Cloutier (2008) has said, "We are an adaptable people. There is no doubt about that. We've had to be." We argue that the archaeological records from these two sites bear witness to this adaptability.

\section{ACKNOWLEDGEMENTS}

We thank Lisa Hodgetts and Patricia Wells for organizing the 2015 CAA session and this publication in honor of Priscilla Renouf. Earlier versions of this paper were presented at the 2012 Chacmool Conference, Calgary, Alberta; Nordic TAG 2013 in Reykjavik, Iceland; and the 2014 Society for Historical Archaeology Conference in Québec. Archaeological research at Iita was funded by National Science Foundation (NSF) grants to LeMoine (OPP-0328773) and Darwent (OPP-0330981). Research at Cape Sheridan was funded by an NSF grant to LeMoine and Kaplan (ARC-1124811). We are also grateful to John Darwent, Hans Lange, and our field crews in 2006 and 2011, to Joanne Bird and Pat Freeman at the Prince of Wales Northern Heritage Centre for their kind assistance, and to three anonymous reviewers for their thoughtful comments, which have strengthened this paper. 


\section{REFERENCES}

Bodenhorn, B. 1990. "I'm not the great hunter, my wife is": Iñupiat and anthropological models of gender. Études/Inuit/ Studies 14(1-2):55-74.

http://www.jstor.org/stable/42869683

Busch, J. 1981. An introduction to the tin can. Historical Archaeology 15(1):95-104.

http://www.jstor.org/stable/25615391

Darwent, J. 2013. Investigation of stratified archaeological deposits at Iita, Foulke Fjord, northwestern Greenland, 2012. Unpubl. report on file at Nunatta Katersugaasivia Allagaateqarfialu/ Greenland National Museum and Archives, Hans Egedesvej 8, Box 145, 3900 Nuuk, Greenland.

Darwent, J., and Johansen, T.B. 2010. Archaeological survey in the Foulke Fjord region, Inglefield Land, northwestern Greenland. Geografisk Tidsskrift-Danish Journal of Geography 110(2):297-314.

http://dx.doi.org/10.1080/00167223.2010.10669513

Darwent, J., Darwent, C., LeMoine, G., and Lange, H. 2007. Archaeological survey of eastern Inglefield Land, Northwest Greenland. Arctic Anthropology 44(2):51 - 86. http://dx.doi.org/10.1353/arc.2011.0048

Darwent, J., Lange, H., LeMoine, G., and Darwent, C. 2008. The longest longhouse in Greenland. Antiquity: A Review of World Archaeology 82(315). http://www.antiquity.ac.uk/projgall/darwent315/

Dick, L. 1995. "Pibloktoq" (Arctic hysteria): A construction of European-Inuit relations? Arctic Anthropology 32(2):1-42. http://www.jstor.org/stable/40316385

- 2001. Muskox Land: Ellesmere Island in the Age of Contact. Calgary, Alberta: University of Calgary Press.

Gilberg, R. 1974/75. Changes in the life of the Polar Eskimos resulting from a Canadian immigration into the Thule District, North Greenland, in the 1860's. Folk 16-17:159-170.

. 1976. The Polar Eskimo population, Thule District, North Greenland. Meddelelser om Grønland 203(3). Copenhagen: Nyt Nordisk Forlag.

- 1988. Inughuit, Knud Rasmussen, and Thule: The work of Knud Rasmussen among the Polar-Eskimos in North Greenland. Études/Inuit/Studies 12(1-2):45-55.

http://www.jstor.org/stable/42869624

. 1996. When the "moon beings" visited the only people in the world: The first ethnographical notes on the Inughuit, A North Greenland Inuit people. In: Jacobsen, B., Andreasen, C., and Rygaard, J., eds. Cultural and social research in Greenland 95/96, Essays in honour of Robert Petersen. Nuuk: Ilisimatusarfik/Atuakkiorfik. 54-72.

Guemple, L. 1986. Men and women, husbands and wives: The role of gender in traditional Inuit society. Études/Inuit/Studies 10(1-2):9-24.

http://www.jstor.org/stable/42869538

Hayes, I.I. 1867. The Open Polar Sea: A narrative of a voyage of discovery towards the North Pole in the Schooner "United States.” New York: Hurd and Houghton.
Holtved, E. 1967. Contributions to Polar Eskimo ethnography. Meddelelser om Grønland 182(2). Copenhagen: C.A. Reitzels Forlag.

Ingold, T. 1993. The temporality of the landscape. World Archaeology 25(2):152-174.

http://www.jstor.org/stable/124811

Johansen, T.B. 2012. A zooarchaeological and ethnographic investigation of subsistence change through time at Iita, Northwest Greenland. $\mathrm{PhD}$ dissertation, Department of Anthropology, University of California.

- 2013. Foraging efficiency and small game: The importance of dovekie (Alle alle) in Inughuit subsistence. Anthropozooloogica 48(1):75-88.

http://dx.doi.org/10.5252/az2013n1a4

Kane, E.K. 1856. Arctic explorations: The Second Grinnell Expedition in search of Sir John Franklin, 1853, '54, '55, 2 vols. Philadelphia: Childs \& Peterson.

LeMoine, G.M. 2009. Figuring out culture contact: Prehistoric and historic miniature ivory carvings from Northwest Greenland. In: Grønnow, B., ed. On the track of the Thule culture from Bering Strait to east Greenland: Proceedings of the SILA conference "The Thule culture - new perspectives in Inuit prehistory," papers in honour of Hans Christian Gulløv. 26-28 October 2006, Copenhagen, Denmark. Publications from the National Museum. Studies in Archaeology and History. Copenhagen: National Museum of Denmark. 144-184.

LeMoine, G.M., and Darwent, C.M. 2010. The Inglefield Land Archaeology Project: Introduction and overview. Geografisk Tidsskrift-Danish Journal of Geography 110(2):279-296. http://dx.doi.org/10.1080/00167223.2010.10669512

_ 2013. Furs and satin: Understanding Inughuit women's role in culture contact through clothing. In: Kaplan, S.A., and McCracken Peck, R., eds. North by degree: New perspectives on Arctic exploration. Philadelphia: American Philosophical Society. $211-236$.

- 2016. Development of Polar Inughuit culture in the Smith Sound region. In: Friesen, T.M., and Mason, O.K., eds. The Oxford handbook of the prehistoric Arctic. Oxford: Oxford University Press. 873-896.

LeMoine, G.M., and Kaplan, S.A. 2011. Report on the Cape Sheridan Archaeology Project, 2011. Report on File with the Department of Culture and Heritage, Box 1000, Stn. 800, Iqaluit, Nunavut X0A 0H0.

Lowenstein, T. 1993. Ancient land: Sacred whale - The Inuit hunt and its rituals. New York: Farrar, Straus and Giroux.

MacMillan, D.B. 1918. Four years in the white North. New York: Harper and Brothers.

— (1934) 2008. How Peary reached the Pole. Reprint with new introduction by G.M. LeMoine, S.A. Kaplan, and A. Witty. Montreal and Kingston: McGill-Queen's University Press.

Mary-Rousselière, G. 1991. Qitdlarssuaq: The story of a polar migration. Translated by A. Cooke. Winnipeg: Wuerz Publishing, Ltd.

Maxwell, M.S. 1960. An archaeological analysis of eastern Grant Land, Ellesmere Island, Northwest Territories. Bulletin 170. Ottawa: National Museum of Canada. 
Münchow, A., and Melling, H. 2008. Ocean current observations from Nares Strait to the west of Greenland: Interannual to tidal variability and forcing. Journal of Marine Research 66(6):801-833.

Nares, G.S., and Feilden, H.W. 1878. Narrative of a voyage to the Polar Sea during 1875-6 in H.M. ships 'Alert' and 'Discovery,' Vols. I and II. London: Sampson Low, Marston, Searle, \& Rivington.

Nuttall, M. 1992. Arctic homeland: Kinship, community, and development in northwest Greenland. Toronto: University of Toronto Press.

Oosten, J.G. 1986. Male and female in Inuit shamanism. Études/ Inuit/Studies 10(1-2):115-131. http://www.jstor.org/stable/42869540

Peary, J.D. 1894. My Arctic journal: A year among ice-fields and Eskimos. New York: The Contemporary Publishing Co.

Peary, R.E. 1898. Northward over the "Great Ice:" A narrative of life and work along the shores and upon the interior ice-cap of northern Greenland in the years 1886 and 1891-1897. New York: Frederick A. Stokes Company.

. 1907. Nearest the pole: A narrative of the polar expedition of the Peary Arctic Club in the S.S. Roosevelt, 1905-1906. New York: Doubleday, Page \& Company.

- 1910. The North Pole: Its discovery in 1909 under the auspices of the Peary Arctic Club. New York: F.A. Stokes.

- 1917. Secrets of polar travel. New York: The Century Co.

Phillips Parmenter, C. 1981. High Arctic Historical Archaeology Project: Fifth season, 1980. Research Bulletin, Parks Canada $165.16 \mathrm{p}$.

- 1987. Eastern Canadian High Arctic exploration as an example of frontier change, with particular emphasis on the Robert Peary North Pole expeditions. MA thesis, Department of Anthropology, University of Manitoba.

Phillips Parmenter, C., and Burnip, M. 1980. Historical archaeology in the eastern High Arctic. Research Bulletin, Parks Canada 137. 21 p.

Phillips Parmenter, C., Burnip, M., and Ferguson, R. 1978. Report on the second season of archaeological investigations of historical sites in the Canadian Arctic Archipelago. Research Bulletin, Parks Canada 81. 26 p.

Rasmussen, K. 1908. The people of the polar North: A record. Compiled from the Danish originals and edited by G. Herring. London: Kegan Paul, Trench, Trübner \& Co. Ltd.

Ross, J. 1819. A voyage of discovery, made under the orders of the Admiralty, in His Majesty's ships Isabella and Alexander, for the purpose of exploring Baffin's Bay, and inquiring into the probability of a North-west Passage. London: J. Murray.
Saladin d'Anglure, B. 1986. Du foetus au chamane : la construction d'un « troisième sexe » inuit. Études/Inuit/Studies 10(12):25-113. http://www.jstor.org/stable/42869539

Ulloriaq, I. 1985. Beretningen om Qillarsuaq og hans lange rejse fra Canada til Nordgrønland i 1860erne [Report of Qillarsuaq and his long journey from Canada to North Greenland in the 1860s]. Translated by R. Gilbert. København: Gullanders Bogtrykkeri.

United States Navy Dept., Hall, C.F., and Davis, C.H. 1876. Narrative of the North Polar expedition. U.S. Ship Polaris, Captain Charles Francis Hall commanding. Washington, D.C.: Government Printing Office.

USNA (United States National Archives). 1798-1976. Collection XP: Rear Adm. Robert E. Peary papers, 1798-1976. College Park, Maryland: National Archives and Records Administration.

— 1901. T.S. Dedrick diary Jan 15-March 1901. In: RG-401 Peary Papers, paper relating to Arctic Expeditions, Greenland $1891-1902$, T. S. Dedrick diaries, notebooks and other papers 1898-1902. Vol. 15. College Park, Maryland: National Archives and Records Administration.

Wardwell, G. 1905-06. Journal, SS Roosevelt. On loan. Brunswick, Maine: The Peary-MacMillan Arctic Museum, Bowdoin College. 1908-09. Journal, SS Roosevelt. On loan. Brunswick, Maine: The Peary-MacMillan Arctic Museum, Bowdoin College.

Watt-Cloutier, S. 2008. Speech to the Governor General's Canadian Leadership conference, 8 June 2008.

http://2008.leadershipcanada.ca/index.php?option=com_conte nt\&task $=$ view\&id $=365 \&$ Itemid $=88 \&$ lang $=$ en

Weisburger, A. 2010. Stitching together the evidence: The role of Inughuit women on the Crocker Land Expedition, 1913-1917. BA Honors thesis, Sociology and Anthropology, Bowdoin College, Brunswick, Maine.

Whitney, H. 1910. Hunting with the Eskimos: The unique record of a sportsman's year among the northernmost tribe-the big game hunting, the native life, and the battle for existence through the long Arctic night. New York: The Century Co.

Whitridge, P. 2004. Landscapes, houses, bodies, things: "Place" and the archaeology of Inuit imaginaries. Journal of Archaeological Method and Theory 11(2):213-250. http://dx.doi.org/10.1023/B:JARM.0000038067.06670.34 